\title{
Skin Temperature in Young Women with Low Values of Adipose Tissue
}

\author{
${ }^{1}$ Vitaliy Viktorovich Epishev, ${ }^{1}$ Anna Valerievna Nenasheva* ${ }^{2}$ Yulia Borisovna Korableva, \\ ${ }^{1}$ Alexander Sergeevich Belenkov, ${ }^{1}$ Alina Azatovna Episheva, ${ }^{3}$ Seyed Morteza Tayebi \\ ${ }^{1}$ Theory and Methods of Physical Education and Sport Department, the Institute of Sports, Tourism and \\ Service, South Ural State University (National Research University), Chelyabinsk, Russia. ${ }^{2}$ Sports Science \\ Research Centre, the Institute of Sports, Tourism and Service, South Ural State University (National \\ Research University), Chelyabinsk, Russia. ${ }^{3}$ Core Research of Health Physiology and Physical Activity, \\ Department of Exercise Physiology, Faculty of Sport Science, Allameh Tabataba'i University, Tehran, Iran.
}

Submitted 19 June 2019; Accepted in final form 23 August 2019.

\begin{abstract}
Background. Skin temperature is an important indicator of the functional status of the body. Infrared thermal images of the body surface or its separate parts could be the indicator of body composition and, probably, the criterion of the functional activity of muscles. Objectives. This study aims to find a correlation between the average values of skin temperature in different parts of the body and the components of body composition in young women with low values of adipose tissue $($ FAT $\%=20.73 \pm 5.50 ; \mathrm{BMI}=20.23 \pm 2.44)$. Methods. The study involved 69 healthy women aged $18-20(\mathrm{BMI}=20.23 \pm 2.44)$. Participants were subjected to a 15 -minute temperature adaptation in the room with a temperature of $22-24^{\circ} \mathrm{C}$ and humidity of $45-50 \%$. We measured body composition using bioelectrical impedance analysis and taking eight photos of different body areas with the help of the thermal infrared camera. Results. Correlation analysis allowed us to reveal temperature correlations with BMI and FAT\%. The most significant values were registered between FAT\% and $\mathrm{t}_{\text {mean }}(\mathrm{r}=-$ 0.36), FAT\% and $t_{\operatorname{shin}} B L(r=-0.39)$, FAT\% and $t_{\operatorname{shin}} B R(r=-0.38)$. Conclusion. To forecast $F A T \%$ for this sample, the skin temperature of the shin is the most informative parameter (decrease by $1 \%$ results in the increase in FAT\% by 1-1.5\%). Moreover, we made a hypothesis that the differences between $t_{\text {mean }}$ of shins and hips indicate the postural balance: $t_{\text {shin }}$ mean $>t_{\text {hip }}$ mean is responsible for the shin strategy; $t_{\text {shin }}$ mean $<t_{\text {hip }}$ mean indicates the hip strategy.
\end{abstract}

\section{KEYWORDS: Young Women, Body Composition, Skin Temperature, Temperature Distribution, Thermal Imaging}

\section{INTRODUCTION}

Skin temperature is an important indicator of the functional status of the body; its assessment is significant in different cases connected with adaptation to environmental factors and muscle activity. It also reveals the intensity of thermal output $(1,2)$. The formation mechanism of such differences can be connected with three main factors: the structure and functional activity of skin capillary network, density and activity of sweat glands, and metabolic activity of tissues located directly under the skin $(3,4)$.

Hypothesis. Infrared thermal images of the body surface or separate parts of the body can be the indicator of body composition.

Aim. This research aims to study the correlation between body composition and the

*. Corresponding Author:

Anna Valerievna Nenasheva, Professor

E-mail: isaeva-susu@yandex.ru 
data on skin temperature for the whole body and its separate parts.

\section{MATERIALS AND METHODS}

The study was conducted in the Research center for Sports science at South Ural State University. The study involved 69 healthy women aged 18-20 years. The study was conducted in the daytime (5). The study was conducted in accordance with the Declaration of Helsinki. All participants expressed their informed consent for taking part in the study. The study was also approved by the ethical committee of South Ural State University.

Before the examination, the participants were subjected to a 15-minute temperature adaptation in a room with a temperature of $22-24^{\circ} \mathrm{C}$ and humidity of $45-50 \%$. All participants were in the condition of muscle rest, sitting or staying naked to the underwear. The choice for such a sample was determined by a relative complexity of data interpretation on body composition and, in particular, BMI (6-8). We suppose that if the hypothesis is confirmed for this sample, it will be proved for other categories of people.

We measured body composition by using Tanita BC-418 analyzer, calculated adipose tissue mass and percentage, and performed thermography with the help of Baltech-TR-01500 non-contact thermal camera. The thermal camera was located at a distance of $2 \mathrm{~m}$ from participants at the height of $150 \mathrm{~cm}$ from the floor. For each participant we made 8 photos (9-11): lower part of the body back view, upper part of the body back view, lower part of the body front view, upper part of the body front view, lower part of the body left view, upper part of the body left view, lower part of the body right view, upper part of the body right view (Fig. 1).

The thermogram data obtained were processed with the help of Baltech Expert specialized program, where for the quantitative analysis, on each image, we selected body areas (Table 1) manually to calculate the average temperature (12) automatically with the accuracy of up to $0.1^{\circ} \mathrm{C}$ or $2 \%$ (Fig. 2). Apart from the temperature of the areas selected, we introduced the additional parameters obtained using the methods of mathematical processing: average body temperature $\left(t_{\text {mean }}\right)$, average temperature of the upper part of the body $\left(t_{\text {mean }} \mathrm{T}\right)$, average temperature of the lower part of the body $\left(t_{\text {mean }} \mathrm{D}\right)$, difference between maximal and minimal temperatures $\left(t_{\max }-t_{\min }\right)$, sum of body temperatures $\left(\sum \mathrm{t}\right)$, body temperature mode $\left(\mathrm{t}_{\mathrm{Mo}}\right)$, average temperature of the right part of the body $\left(\mathrm{t}_{\text {mean }} \mathrm{R}\right)$, average temperature of the left part of the body $\left(t_{\text {mean }} L\right)$, average temperature of the front part of the body $\left(\mathrm{t}_{\text {mean }} \mathrm{F}\right)$, average temperature of the back part of the body $\left(t_{\text {mean }} B\right)$, temperature difference between the right and left parts of the body $\left(t_{\text {mean }} R\right.$ - $t_{\text {mean }} L$ ), temperature difference between the front and back parts of the body $\left(\mathrm{t}_{\text {mean }} \mathrm{F}-\mathrm{t}_{\text {mean }} \mathrm{B}\right)$, average hip temperature ( $\mathrm{t}$ hip mean $)$, average shin temperature $\left(\mathrm{t} \operatorname{shin}_{\text {mean }}\right)$, temperature difference between hips and shins ( $\mathrm{t}$ hip mean-t $\operatorname{shin}_{\text {mean }}$ ), temperature difference between the average and mode temperatures $\left(t_{\text {mean }}-t_{M o}\right)$.

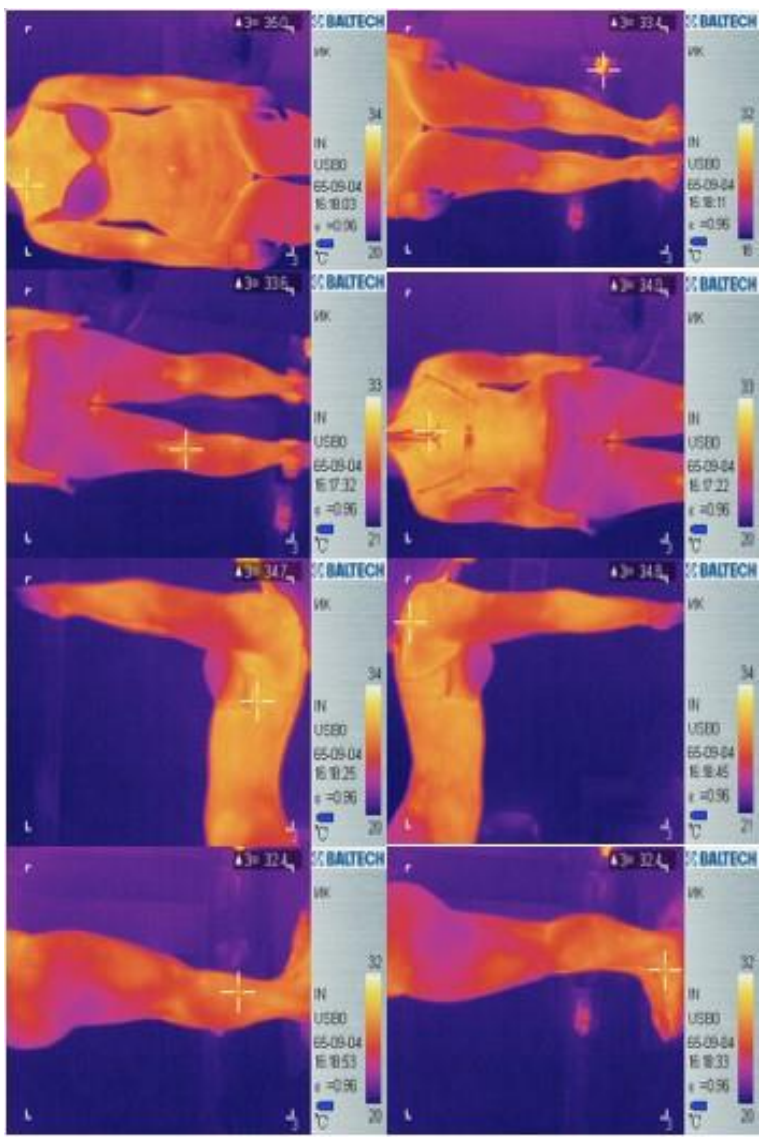

Figure 1. Example of thermal images

With the help of Tanita BC-418 body composition analyzer (input data: body type standard, gender - female, age, body length) we registered the following parameters: body mass index (BMI), adipose tissue percentage (FAT\%), adipose tissue mass, $\mathrm{kg}$ (FAT MASS), body mass without adipose tissue, $\mathrm{kg}$ (FFM), total body water, $\mathrm{kg}$ (TBW), adipose tissue percentage of the right leg $\left(\mathrm{FAT} \%_{\mathrm{RL}}\right)$, of the left leg $\left(\mathrm{FAT} \%_{\mathrm{LL}}\right)$, of the right arm (FAT\% $\%_{\text {RA }}$ ), of the left arm (FAT\% $\%_{\mathrm{LA}}$ ), of the trunk (FAT\% TRUNK ); adipose 
tissue mass $(\mathrm{kg})$ of the right leg (FAT MASS $\mathrm{RL}_{\mathrm{R}}$ ), of the left leg (FAT MASS $S_{\mathrm{LL}}$ ), of the left arm (FAT MASS $\mathrm{FA}_{\mathrm{LA}}$ ), of the right arm (FAT MASS $\mathrm{FA}_{\mathrm{RA}}$ ), of the trunk (FAT MASS TRUNK $_{\text {); mass }}(\mathrm{kg})$ of the right leg $\left(\mathrm{FFM}_{\mathrm{RL}}\right)$, of the left leg $\left(\mathrm{FFM}_{\mathrm{LL}}\right)$, of the right $\operatorname{arm}\left(\mathrm{FFM}_{\mathrm{RA}}\right)$, of the left $\operatorname{arm}\left(\mathrm{FFM}_{\mathrm{LA}}\right)$, of the trunk $\left(\mathrm{FFM}_{\mathrm{TRUNK}}\right)$ without adipose tissue; muscle mass $(\mathrm{kg})$ of the right leg (MUSCLE MASS $\mathrm{RL}_{\mathrm{L}}$ ), of the left leg (MUSCLE MASS $\mathrm{LL}_{\mathrm{L}}$ ), of the right arm (MUSCLE MASS $\mathrm{RA}_{\mathrm{RA}}$ ), of the left arm (MUSCLE MASS $\mathrm{LA}_{\mathrm{LA}}$ ), of the trunk (MUSCLE MASS $_{\text {TRUNK }}$. Moreover, we also calculated the following parameters: difference in the percentage of adipose tissue between the trunk and legs (average values of the right and left legs), $\%$, (FAT\% TRUNK - FAT\% $\%_{\text {LEG }}$ ); difference in the percentage of adipose tissue between the trunk and arms (average values of the right and left arms), $\%$, (FAT\% TRUNK - FAT\% $\%_{\text {ARM }}$ ); difference in the percentage of adipose tissue between legs and arms (FAT\% $\%_{\text {LEG }}-$ FAT\% $\left.\%_{\text {ARM }}\right)$.

\section{DISCUSSION}

The study of body composition with the help of bioelectrical impedance analysis is one of the most accurate non-invasive methods with a measurement error for some parameters (in comparison with the hydrodensitometry and dual x-ray absorptiometry) of no more than $5 \%$ (1316).

Human skin is an almost perfect emitter of infrared radiation in the spectral region beyond 3 microns. This energy may be recorded as a thermogram to yield a quantitative temperature map of the skin. If the nude subject has remained quiet in a cool room for 10 to 15 minutes prior to thermography, the skin temperatures are determined largely by the vascularity of the skin itself and by the heat conducted from within the body (17). Therefore, if we take into account that the greater the depth of the subcutaneous fat the more its mass and the less heat loss $(18,19)$, then we can assume correlations and certain dependencies (20-23), the establishment of which will allow the creation of a technique and device to estimate the content of adipose tissue with the help of skin temperature measurements.

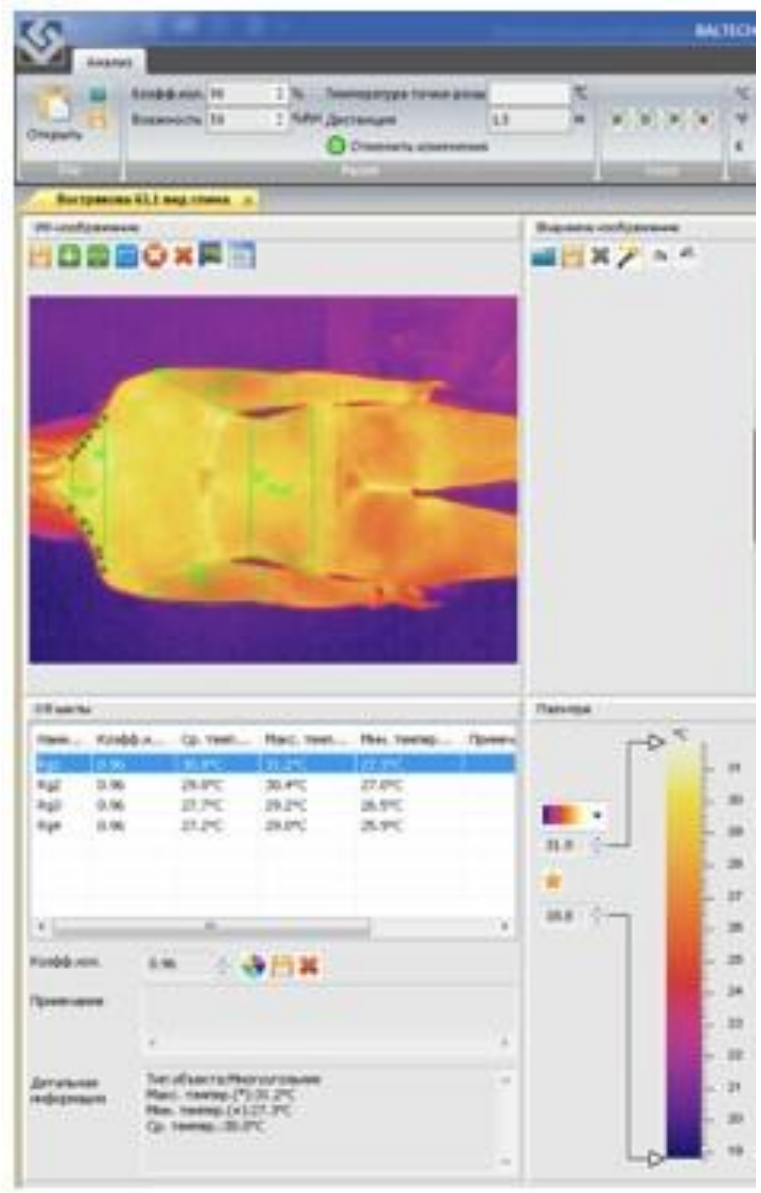

Figure. 2. Example of thermogram processing in Baltech Expert program

Table 1. Body areas analyzed in Baltech Expert program

\begin{tabular}{|c|c|c|c|c|c|c|c|}
\hline \multicolumn{2}{|c|}{ Back view } & \multicolumn{2}{|c|}{ Front view } & \multicolumn{2}{|c|}{ Left view } & \multicolumn{2}{|c|}{ Right view } \\
\hline $\begin{array}{l}\text { Lower part of } \\
\text { the body }\end{array}$ & $\begin{array}{l}\text { Upper part of } \\
\text { the body }\end{array}$ & $\begin{array}{c}\text { Lower part of } \\
\text { the body }\end{array}$ & $\begin{array}{l}\text { Upper part of } \\
\text { the body }\end{array}$ & $\begin{array}{c}\text { Lower part of } \\
\text { the body }\end{array}$ & $\begin{array}{l}\text { Upper part of } \\
\text { the body }\end{array}$ & $\begin{array}{c}\text { Lower part of } \\
\text { the body }\end{array}$ & $\begin{array}{l}\text { Upper part of } \\
\text { the body }\end{array}$ \\
\hline$t_{\text {shin }} B L$ & $\mathrm{t}_{\text {collar }}$ & $\mathrm{t}_{\text {shin }} \mathrm{FL}$ & $\mathrm{t}_{\text {celiac plexus }}$ & $t_{\text {shin }} \mathrm{L}$ & $t_{\text {neck }} \mathrm{L}$ & $t_{\text {shin }} R$ & $t_{\text {neck }} R$ \\
\hline$t_{\text {shin }} B R$ & $t_{\text {waist }} B$ & $t_{\text {shin }} F R$ & $\mathrm{t}_{\text {waist }} \mathrm{F}$ & $t_{\text {shin }} L$ & $t_{\text {axilla }} \mathrm{L}$ & $t_{\text {shin }} R$ & $t_{\text {axilla }} R$ \\
\hline$t_{\text {hip }} B L$ & $\mathrm{t}_{\mathrm{arm}} \mathrm{BL}$ & $t_{\text {hip }} F L$ & $\mathrm{t}_{\mathrm{arm}} \mathrm{FL}$ & $\mathrm{t}_{\text {hip }} \mathrm{L}$ & $\mathrm{t}_{\text {waist }} \mathrm{L}$ & $t_{\text {hip }} R$ & $\mathrm{t}_{\text {waist } \mathrm{R}}$ \\
\hline$t_{\text {hip }} B R$ & $\mathrm{t}_{\mathrm{arm}} \mathrm{BR}$ & $t_{\text {hip }} F R$ & $\mathrm{t}_{\mathrm{arm}} \mathrm{FR}$ & $\mathrm{t}_{\text {hip }} \mathrm{L}$ & $\mathrm{t}_{\mathrm{arm}} \mathrm{L}$ & $t_{\text {hip }} R$ & $t_{\mathrm{arm}} R$ \\
\hline
\end{tabular}

$t_{\text {shin }}$ BL: Left shin back view. $t_{\text {collar: }}$ Collar area. $t_{\text {shin }}$ FL: Left shin front view. $t_{\text {celiac plexus: }}$ Celiac plexus. $t_{\text {neck }} L$ : Neck left view. $t_{\text {neck }} R:$ Neck right view. $t_{\text {shin }}$ BR: Right shin back view. $t_{\text {waist }} B$ : Waist back view. $t_{\text {shin }}$ FR: Right shin front view. $t_{\text {waist }} F$ : Waist front view. $t_{\text {shin }} L$ : Shin left view. $t_{\text {axilla }} L$ : Axilla left view. $t_{\text {shin }} R$ : Shin right view. $t_{\text {axilla }} R$ : Axilla right view. $t_{\text {hip }}$ BL: Left hip back view. $t_{\text {arm }}$ BL: Left arm back view (shoulder

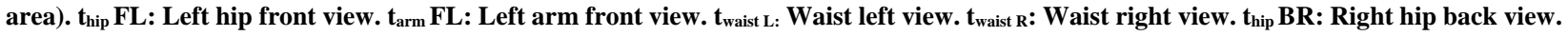
$t_{a r m}$ BR: Right arm back view (shoulder area). $t_{\text {hip }}$ FR: Right hip front view. $t_{a r m}$ FR: Right arm front view. $t_{\text {hip }} L$ : Hip left view. $t_{a r m} L$ : Arm left view (shoulder area). $t_{\text {hip }} R$ : Hip right view. $t_{\text {arm }} R$ : Arm right view (shoulder area).

The study of women with obesity (22) revealed that $\mathrm{t}_{\text {mean }}$ decreases with an increase in the percentage of fat deposits in the abdominal area. It also revealed a negative correlation between BMI and $\mathrm{t}_{\text {mean }}$ of the hips both in the front and back parts. During the study (24), healthy 
volunteers were divided into groups, according to a health risk classification based on $\mathrm{BF} \%$. The highest correlations in women were observed between posterior trunk and $\mathrm{BF} \%$ (rho $=-0,564$, $\mathrm{p}<0,001)$ and, in men, between anterior trunk and $\mathrm{BF} \%$ (rho $=-0,760, \mathrm{p}<0,001)$. The study of fat percentage and skin temperature in women aged $26.11 \pm 4.41$ revealed the accuracy of $58.3 \%$ in predicting fat percentage with the help of skin temperature and body circumference.

Table 2. Body composition parameters

\begin{tabular}{|c|c|c|c|c|}
\hline Parameter & Mean & Minimum & Maximum & Std.Dev \\
\hline Age & 19,29 & 18,00 & 21,00 & 0,75 \\
\hline Body length & 163,94 & 151,00 & 180,00 & 5,44 \\
\hline Body mass & 54,45 & 36,90 & 79,80 & 7,77 \\
\hline BMI & 20,23 & 14,40 & 26,80 & 2,44 \\
\hline FAT $\%$ & 20,73 & 7,80 & 36,60 & 5,50 \\
\hline FAT MASS & 11,62 & 2,90 & 25,60 & 4,54 \\
\hline FFM & 42,84 & 33,80 & 56,60 & 4,12 \\
\hline TBW & 31,36 & 24,70 & 41,40 & 3,02 \\
\hline FAT \% ${ }_{R L}$ & 27,19 & 19,30 & 38,20 & 4,10 \\
\hline FAT MASSRL & 2,81 & 1,40 & 4,90 & 0,71 \\
\hline FFM $_{R L}$ & 7,37 & 5,70 & 9,50 & 0,66 \\
\hline $\begin{array}{l}\text { MUSCLE } \\
\text { MASS }_{R L}\end{array}$ & 6,95 & 5,40 & 9,00 & 0,62 \\
\hline FAT\% $\%_{L L}$ & 27,20 & 17,60 & 37,90 & 4,18 \\
\hline FAT MASS $_{L L}$ & 2,72 & 0,60 & 4,80 & 0,75 \\
\hline FFM $_{L L}$ & 7,11 & 2,40 & 9,20 & 0,84 \\
\hline $\begin{array}{l}\text { MUSCLE } \\
\text { MASS }_{L L}\end{array}$ & 6,70 & 2,20 & 8,60 & 0,80 \\
\hline FAT $\%_{\mathrm{RA}}$ & 21,00 & 4,40 & 39,70 & 6,63 \\
\hline FAT MASS $_{R A}$ & 0,55 & 0,10 & 1,30 & 0,24 \\
\hline FFM $_{\text {RA }}$ & 2,02 & 1,40 & 3,50 & 0,32 \\
\hline $\begin{array}{l}\text { MUSCLE } \\
\text { MASS }_{\text {RA }}\end{array}$ & 1,89 & 1,30 & 3,30 & 0,30 \\
\hline FAT\% \% & 21,68 & 4,80 & 38,20 & 6,20 \\
\hline FAT MASS MA $_{\text {A }}$ & 0,58 & 0,10 & 1,40 & 0,26 \\
\hline FFM $_{L A}$ & 1,99 & 1,40 & 3,10 & 0,29 \\
\hline $\begin{array}{l}\text { MUSCLE } \\
\text { MASS }_{L A}\end{array}$ & 1,85 & 1,30 & 2,80 & 0,26 \\
\hline FAT\% \% TRUNK & 16,25 & 3,00 & 35,20 & 6,66 \\
\hline $\begin{array}{l}\text { FAT } \\
\text { MASS }_{\text {TRUNK }}\end{array}$ & 4,99 & 0,60 & 14,10 & 2,70 \\
\hline FFM $_{\text {TRUNK }}$ & 24,30 & 18,60 & 32,90 & 2,35 \\
\hline $\begin{array}{l}\text { MUSCLE } \\
\text { MASS }_{\text {TRUNK }}\end{array}$ & 23,21 & 17,80 & 31,50 & 2,26 \\
\hline $\begin{array}{l}\text { FAT\% } \% \text { TRUNK } \\
\text { - FAT \% LEG }\end{array}$ & $-10,95$ & $-22,30$ & $-0,55$ & 4,11 \\
\hline $\begin{array}{l}\text { FAT\% } \% \text { TRUNK - } \\
\text { FAT\% }\end{array}$ & $-5,09$ & $-14,15$ & 5,45 & 3,47 \\
\hline $\begin{array}{l}\text { FAT\% LEG - } \\
\text { FAT \% ARM }\end{array}$ & $-5,86$ & $-22,00$ & 0,90 & 4,09 \\
\hline
\end{tabular}

Std.Dev.: standard deviation. BMI: body mass index. FFM: body mass without adipose tissue (Fat Free mass). TBW: total body water. FAT \% ${ }_{\mathrm{RL}}$ adipose tissue percentage of the right leg. FAT MASS ${ }_{\mathrm{RL}}$ : adipose tissue mass $(\mathrm{kg})$ of the right leg. FFM RL: mass $(\mathrm{kg})$ of the right leg. MUSCLE MASS ${ }_{\mathrm{RL}}$ : muscle mass $(\mathrm{kg})$ of the right leg. FAT\% $\%_{\mathrm{LL}}$ : adipose tissue percentage of the left leg. FAT MASS ${ }_{L L}$ : adipose tissue mass $(\mathrm{kg})$ of the left leg. FFM $M_{L L}$ mass $(\mathrm{kg})$ of the left leg. MUSCLE MASS $_{L L}$ muscle mass $(\mathrm{kg})$ of the left leg. FAT\% ${ }_{\mathrm{RA}}$ : adipose tissue percentage of the right arm. FAT MASS $_{\mathrm{RA}}$ adipose tissue mass $(\mathrm{kg})$ of the right $\mathrm{arm}$. FFM $\mathrm{RA}_{\mathrm{R} \text { : }}$ mass $(\mathrm{kg})$ of the right arm. MUSCLE MASS ${ }_{\mathrm{RA}}$ : muscle mass $(\mathrm{kg})$ of the of the right arm. FAT\% $\%_{\text {LA: }}$ adipose tissue percentage of the left arm. FAT MASS ${ }_{L A}$ adipose tissue mass $(\mathrm{kg})$ of the left arm. FFM $_{\mathrm{LA}}$ mass $(\mathrm{kg})$ of the left arm. MUSCLE MASS $_{\mathrm{LA}}$ : muscle mass $(\mathrm{kg})$ of the left arm.
Table 3. Parameters of skin temperature in different parts of the body

\begin{tabular}{|c|c|c|c|c|}
\hline & Mean & Minimum & Maximum & Std.Dev \\
\hline$t_{\text {neck }} L$ & 34,67 & 29,90 & 37,70 & 1,45 \\
\hline $\mathbf{t}_{\text {neck }} \mathbf{R}$ & 34,55 & 30,00 & 37,00 & 1,36 \\
\hline$t_{\text {axillaa }} \mathbf{L}$ & 34,72 & 31,30 & 38,00 & 1,36 \\
\hline$t_{\text {axilla }} \mathbf{R}$ & 34,52 & 31,50 & 37,40 & 1,10 \\
\hline $\mathbf{t}_{\text {celiac plexus }}$ & 33,58 & 28,80 & 36,10 & 1,47 \\
\hline$t_{\text {collar }}$ & 34,79 & 30,10 & 37,40 & 1,25 \\
\hline$t_{\text {waist }} F$ & 33,24 & 28,70 & 35,70 & 1,38 \\
\hline $\mathbf{t}_{\text {waist }}$ B & 33,11 & 29,00 & 36,20 & 1,45 \\
\hline $\mathbf{t}_{\text {waist }} \mathbf{R}$ & 33,04 & 30,10 & 35,70 & 1,24 \\
\hline $\mathbf{t}_{\text {waist }} \mathbf{L}$ & 33,02 & 28,70 & 36,10 & 1,45 \\
\hline$t_{\mathrm{arm}} \mathbf{B L}$ & 31,52 & 27,40 & 34,50 & 1,49 \\
\hline $\mathbf{t}_{\mathrm{arm}} \mathbf{B R}$ & 31,61 & 27,60 & 35,40 & 1,35 \\
\hline$t_{\mathrm{arm}} \mathrm{FL}$ & 33,21 & 30,40 & 35,60 & 1,24 \\
\hline$t_{\text {arm }}$ FR & 32,99 & 29,00 & 35,50 & 1,41 \\
\hline$t_{\mathrm{arm}} \mathbf{R}$ & 31,99 & 28,90 & 35,20 & 1,30 \\
\hline$t_{\text {arm }} L$ & 31,81 & 28,60 & 34,90 & 1,36 \\
\hline $\mathbf{t}_{\text {shin }} \mathbf{B L}$ & 31,04 & 28,20 & 34,10 & 1,34 \\
\hline $\mathbf{t}_{\text {shin }} \mathbf{B R}$ & 31,18 & 28,60 & 34,30 & 1,27 \\
\hline$t_{\text {shin }}$ FL & 31,58 & 27,50 & 33,80 & 1,39 \\
\hline $\mathbf{t}_{\text {shin }} \mathbf{F R}$ & 31,56 & 27,60 & 33,80 & 1,34 \\
\hline $\mathbf{t}_{\text {shin }} \mathbf{R}$ & 31,43 & 28,90 & 34,10 & 1,20 \\
\hline$t_{\text {shin }} L$ & 31,54 & 28,70 & 34,10 & 1,25 \\
\hline$t_{\text {hip }} \mathbf{B L}$ & 30,88 & 27,50 & 34,60 & 1,61 \\
\hline $\mathbf{t}_{\text {hip }} \mathbf{B R}$ & 31,12 & 27,60 & 34,60 & 1,58 \\
\hline$t_{\text {hip }} \mathbf{F L}$ & 31,19 & 26,70 & 33,70 & 1,52 \\
\hline $\mathbf{t}_{\text {hip }} \mathbf{F R}$ & 31,08 & 26,60 & 33,60 & 1,56 \\
\hline $\mathbf{t}_{\text {hip }} \mathbf{R}$ & 30,61 & 27,30 & 33,70 & 1,42 \\
\hline $\mathbf{t}_{\text {hip }} \mathbf{L}$ & 30,50 & 27,00 & 33,00 & 1,52 \\
\hline $\mathbf{t}_{\text {mean }}$ & 32,31 & 29,58 & 34,89 & 1,08 \\
\hline$t_{\text {mean }} T$ & 33,27 & 30,52 & 36,06 & 1,06 \\
\hline$t_{\text {mean }} D$ & 31,03 & 27,54 & 33,62 & 1,32 \\
\hline $\mathbf{t}_{\max }-\mathbf{t}_{\min }$ & 5,77 & 3,90 & 9,30 & 1,23 \\
\hline$\sum \mathbf{t}$ & $\begin{array}{l}904,7 \\
3\end{array}$ & 828,10 & 976,90 & 30,37 \\
\hline $\mathbf{t}_{\mathrm{Mo}}$ & 32,59 & 28,80 & 36,10 & 1,61 \\
\hline$t_{\text {mean }} L$ & 32,10 & 29,19 & 34,67 & 1,14 \\
\hline $\mathbf{t}_{\text {mean }} \mathbf{R}$ & 32,06 & 28,86 & 34,63 & 1,15 \\
\hline$t_{\text {mean }} \mathbf{F}$ & 32,76 & 28,94 & 35,15 & 1,24 \\
\hline $\mathbf{t}_{\text {mean }} B$ & 31,85 & 27,79 & 34,54 & 1,32 \\
\hline $\mathbf{t}_{\text {mean }} \mathbf{R}-\mathbf{t}_{\text {mean }} \mathbf{L}$ & $-0,05$ & $-2,18$ & 0,73 & 0,35 \\
\hline $\mathbf{t}_{\text {mean }} \mathbf{F}-\mathbf{t}_{\text {mean }} \mathbf{B}$ & 0,92 & $-1,34$ & 4,21 & 1,01 \\
\hline$t_{\text {hipmean }}$ & 30,75 & 26,22 & 33,65 & 1,57 \\
\hline $\mathbf{t}_{\text {shinmean }}$ & 31,31 & 25,73 & 33,95 & 1,31 \\
\hline $\begin{array}{l}\text { t hipmean- } \\
\mathbf{t}_{\text {shinmean }}\end{array}$ & 0,56 & $-3,62$ & 5,35 & 1,19 \\
\hline$t_{\text {mean }}-t_{M o}$ & $-0,28$ & $-4,14$ & 2,28 & 1,45 \\
\hline
\end{tabular}

Std.Dev.: standard deviation. $t_{\text {neck }} L$ : Neck left view. $t_{\text {neck }} R$ : Neck right view. $t_{\text {axilla }} L$ : Axilla left view. $t_{\text {axilla }} R$ : Axilla right view. $t_{\text {celiac plexus: }}$ Celiac plexus. $t_{\text {collar: }}$ Collar area. $t_{\text {wais }} F$ : Waist front view. $t_{\text {waist }} B$ : Waist back view. $t_{\text {waist }} R$ : Waist right view. $t_{\text {wais }} L$ : Waist left view. $t_{\text {arm }}$ BL: Left arm back view (shoulder area). $t_{\text {arm }}$ BR: Right arm back view (shoulder area). $t_{\text {arm }}$ FL: Left arm front view. $t_{\text {arm }}$ FR: Right arm front view. $t_{\text {arm }}$ R: Arm right view (shoulder area). $t_{\text {arm }} L$ : Arm left view (shoulder area). $t_{\text {shin }}$ BL: Left shin back view. $t_{\text {shin }}$ BR: Right shin back view. $t_{\text {shin }}$ FL: Left shin front view. $t_{\text {shin }}$ FR: Right shin front view. $t_{\text {shin }}$ R: Shin right view. tshin L: Shin left view. thip BL: Left hip back view. thip BR: Right hip back view. thip FL: Left hip front view. thip FR: Right hip front view. thip R: Hip right view. thip $L$ : Hip left view. $t_{\text {mean: average }}$ body temperature. $t_{\text {mean }} \mathrm{T}$ : average temperature of the upper part of the body. $t_{\text {mean }} \mathrm{D}$ : average temperature of the lower part of the body. $t_{\text {max }} t_{\text {min: }}$ difference between maximal and minimal temperatures. $\sum t$ : sum of body temperatures. $t_{M o}$ : body temperature mode. $t_{\text {mean }} L$ : average temperature of the left part of the body. $t_{\text {mean }} R$ : average temperature of the right part of the body. $t_{\text {mean }} F$ : average temperature of the front part of the body. $t_{\text {mean }} B$ : average temperature of the back part of the body. $t_{\text {mean }} R$ - $t_{\text {mean }} L$ : temperature difference between the right and left parts of the body. $t_{\text {mean }} F-t_{\text {mean }} B$ : temperature difference between the front and back parts of the body. $t$ hipmean: average hip temperature. $t$ shinmean: average shin temperature. $t$ hipmean$t$ shinmean: temperature difference between hips and shins. $t_{\text {mean }} \mathbf{t}_{\mathrm{Mo}}$ : temperature difference between the average and mode temperatures. 
Table 4. Results of the correlation analysis between body composition parameters and skin temperature in different parts of the body

\begin{tabular}{|c|c|c|c|c|c|}
\hline & RMI & $\frac{\text { FAT\% }}{\text { Fat }}$ & FAT MACS & FFM & TRW \\
\hline BMI & & 0,80 & 0,86 & 0,66 & 0,66 \\
\hline FAT $\%$ & 0,80 & & 0,96 & 0,38 & 0,38 \\
\hline FAT MASS & 0,86 & 0,96 & & 0,59 & 0,59 \\
\hline FFM & 0,66 & 0,38 & 0,59 & & \\
\hline TBW & 0,66 & 0,38 & 0,59 & & \\
\hline $\mathbf{t}_{\text {neck}} \mathbf{L}$ & $-0,31$ & $-0,34$ & $-0,31$ & & \\
\hline $\mathbf{t}_{\text {neck }} \mathbf{R}$ & $-0,27$ & $-0,31$ & $-0,27$ & & \\
\hline$t_{\text {axilla }} \mathbf{L}$ & & $-0,28$ & & & \\
\hline \multicolumn{6}{|l|}{$t_{\text {axilla }} R$} \\
\hline \multicolumn{6}{|l|}{$\mathbf{t}_{\text {celiac plexus }}$} \\
\hline$t_{\text {collar }}$ & $-0,37$ & $-0,34$ & $-0,33$ & & \\
\hline$t_{\text {waist }} F$ & $-0,27$ & $-0,26$ & & & \\
\hline $\mathbf{t}_{\text {waist }} \mathbf{B}$ & $-0,36$ & $-0,35$ & $-0,35$ & $-0,25$ & $-0,24$ \\
\hline $\mathbf{t}_{\text {waist }} \mathbf{R}$ & $-0,27$ & $-0,27$ & $-0,27$ & & \\
\hline $\mathbf{t}_{\text {waist }} L$ & $-0,28$ & $-0,27$ & $-0,27$ & & \\
\hline$t_{\text {arm }} B L$ & & $-0,28$ & $-0,27$ & & \\
\hline$t_{\text {arm }} B R$ & $-0,26$ & $-0,31$ & $-0,29$ & & \\
\hline$t_{\text {arm }} F L$ & $-0,26$ & $-0,29$ & & & \\
\hline$t_{\text {arm }} F R$ & & $-0,26$ & & & \\
\hline$t_{a r m} R$ & & $-0,29$ & & & \\
\hline$t_{a r m} L$ & $-0,33$ & $-0,40$ & $-0,35$ & & \\
\hline$t_{\text {shin }} B L$ & $-0,29$ & $-0,39$ & $-0,37$ & & \\
\hline $\mathbf{t}_{\text {shin }} \mathbf{B R}$ & $-0,29$ & $-0,38$ & $-0,33$ & & \\
\hline $\mathbf{t}_{\text {shin }} \mathbf{F L}$ & $-0,30$ & $-0,25$ & $-0,25$ & & \\
\hline$t_{\text {shin }} \mathbf{F R}$ & $-0,30$ & $-0,30$ & $-0,27$ & & \\
\hline $\mathbf{t}_{\text {shin }} \mathbf{R}$ & & $-0,27$ & & & \\
\hline $\mathbf{t}_{\text {shin }} \mathbf{L}$ & $-0,26$ & $-0,28$ & & & \\
\hline $\mathbf{t}_{\text {hip }} \mathbf{B L}$ & $-0,31$ & $-0,36$ & $-0,35$ & & \\
\hline$t_{\text {hip }} B R$ & $-0,31$ & $-0,33$ & $-0,33$ & $-0,26$ & $-0,26$ \\
\hline $\mathbf{t}_{\text {hip }} \mathbf{F L}$ & $-0,26$ & & & & \\
\hline \multicolumn{6}{|l|}{$t_{\text {hip }}$ FR } \\
\hline \multicolumn{6}{|l|}{$\mathbf{t}_{\text {hip }} \mathbf{R}$} \\
\hline \multicolumn{6}{|l|}{$t_{\text {hip }} \mathbf{L}$} \\
\hline $\mathbf{t}_{\text {mean }}$ & $-0,33$ & $-0,36$ & $-0,33$ & & \\
\hline$t_{\text {mean }} T$ & $-0,32$ & $-0,36$ & $-0,32$ & & \\
\hline $\mathbf{t}_{\text {mean }} \mathbf{D}$ & $-0,31$ & $-0,35$ & $-0,30$ & & \\
\hline \multicolumn{6}{|l|}{$t_{\max }-t_{\min }$} \\
\hline$\sum \mathbf{t}$ & $-0,33$ & $-0,36$ & $-0,33$ & & \\
\hline$t_{M o}$ & & $-0,31$ & $-0,29$ & & \\
\hline$t_{\text {mean }} L$ & $-0,34$ & $-0,37$ & $-0,34$ & & \\
\hline$t_{\text {mean }} R$ & $-0,29$ & $-0,33$ & $-0,30$ & & \\
\hline$t_{\text {mean }} F$ & $-0,29$ & $-0,28$ & $-0,26$ & & \\
\hline$t_{\text {mean }} B$ & $-0,35$ & $-0,40$ & $-0,38$ & & \\
\hline$t_{\text {mean }} R-t_{\text {mean }} L$ & 0,33 & 0,27 & 0,27 & & \\
\hline $\mathbf{t}_{\text {mean }} \mathbf{F}-\mathbf{t}_{\text {mean }} \mathbf{B}$ & & & & & \\
\hline
\end{tabular}

BMI: body mass index. FAT MASS: adipose tissue mass, kg. FFM: body mass without adipose tissue, $\mathrm{kg}$. TBW: total body water, kg. $\mathrm{t}_{\text {neck }} \mathrm{L}$ :

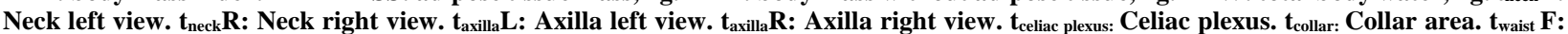
Waist front view. $t_{\text {waist }} B$ : Waist back view. $t_{\text {waist }} R$ : Waist right view. $t_{\text {waist }} L$ : Waist left view. $t_{\text {arm }}$ BL: Left arm back view (shoulder area). $t_{\text {arm }}$ BR: Right arm back view (shoulder area). $t_{\text {arm }}$ FL: Left arm front view. $t_{\text {arm }}$ FR: Right arm front view. $t_{\text {arm }}$ R: Arm right view (shoulder area). $t_{\text {arm }}$ L: Arm left view (shoulder area). $t_{s h i n}$ BL: Left shin back view. $t_{s h i n}$ BR: Right shin back view. $t_{\text {shin }}$ FL: Left shin front view. $t_{\text {shin }}$ FR: Right shin front view. $t_{\text {shin }}$ R: Shin right view. $t_{\text {shin }}$ L: Shin left view. $t_{\text {hip }}$ BL: Left hip back view. thip BR: Right hip back view. $t_{\text {hip }}$ FL: Left hip front view. $t_{\text {hip }}$ FR: Right hip front view. $t_{\text {hip }}$ R: Hip right view. $t_{\text {hip }} L$ : Hip left view. $t_{\text {mean: }}$ average body temperature. $t_{\text {mean }} T$ : average temperature of the upper part of the body. $t_{\text {mean }} D$ : average temperature of the lower part of the body. $t_{\max }-t_{\min }$ difference between maximal and minimal temperatures. $\sum t$ : sum of body temperatures. $t_{M 0}$ : body temperature mode. $t_{\text {mean }} L$ : average temperature of the left part of the body. $t_{\text {mean }} R$ : average temperature of the right part of the body. $t_{\text {mean }} F$ : average temperature of the front part of the body. $t_{\text {mean }} B$ : average temperature of the back part of the body. $t_{\text {mean }} R-t_{\text {mean }} L$ : temperature difference between the right and left parts of the body. $t_{\text {mean }} F-t_{\text {mean }} B$ : temperature difference between the front and back parts of the body.

In our study, the average values of BMI corresponded to normal values and were within the range of $10-15 \%$ and, in terms of body mass and body length, within the range of 5\% (reference age 20 years) (25). Results of the analysis of the average fat percentage revealed underfat values (26). At the same time, the percentage of adipose tissue in limbs was significantly higher than its values in the trunk; this is particularly obvious due to the analysis of FAT\% $\%$ TRUNK - FAT\% LEG - $10.95 \%$ (Table 2). We can assume that such a dispersion is the result of the initial symptoms of a venous outflow disturbance due to the hypertonia of shin muscles (literally the mechanical compression of deep veins). As a result, adipose tissue as a source of energy is spent primarily in the areas with better blood circulation, for example, in the trunk, 
resulting in such pronounced differences. Probably, when studying young women, it is necessary to pay attention not only to BMI and FAT\%, but to conduct a comparative assessment of FAT\% in the limbs and trunk.

Average values of $t_{\text {mean }}$ were $32.31 \pm 1.08 \mathrm{C}^{\circ}$ (Table 3 ) with a variability of approximately $3 \mathrm{C}^{\circ}$ being almost identical to the parameters of $t_{M o}$ (Fig. 3). The maximal temperature was registered in the area of the celiac plexus $\left(\mathrm{t}_{\text {celiac plexus }}=\right.$ $34.79 \pm 1.25 \mathrm{C}^{\circ}$ ), while the minimum temperature was registered in the outer part of the left hip $\left(\mathrm{t}_{\text {hip }} \mathrm{L}\right.$ $\left.=30.50 \pm 1.52 \mathrm{C}^{\circ}\right)$. The average temperature dispersion $\left(\mathrm{t}_{\max }-\mathrm{t}_{\min }\right)$ of the body was $5.77 \pm 1.23$ $\mathrm{C}^{\circ}$, the minimal individual dispersion was equal $3.9 \mathrm{C}^{\circ}$ (girl with a body length of $158 \mathrm{~cm}$, body weight $53.9 \mathrm{~kg}$, BMI $21.6 \mathrm{~kg} / \mathrm{m}^{2}$, FAT\% 22.9), and the individual maximal dispersion was equal to $9.3 \mathrm{C}^{\circ}$ (girl with a body length of $170 \mathrm{~cm}$, body weight $48.8 \mathrm{~kg}$, BMI $15.9 \mathrm{~kg} / \mathrm{m}^{2}$, FAT\% 14.7). We can assume that the girl with an obvious mass deficiency demonstrates the disturbances of thermoregulation. For example, a maximal temperature of $36.9 \mathrm{C}^{\circ}$ was registered in a collar area, while a minimum temperature of $28.7 \mathrm{C}^{\circ}$ was fixed in the outer part of the left hip. It correlates negatively with FAT\% in the trunk (10.3) and legs (21.2) (FAT\% TRUNK $_{\text {TRAT }}$ FAEG $=$ $10.9 \%)$. Therefore, the study of differences between maximal and minimal skin temperatures together with a comparative assessment of FAT\% of the trunk and limbs can be regarded as a diagnostic criterion for Anorexia Nervosa or other nervous diseases.

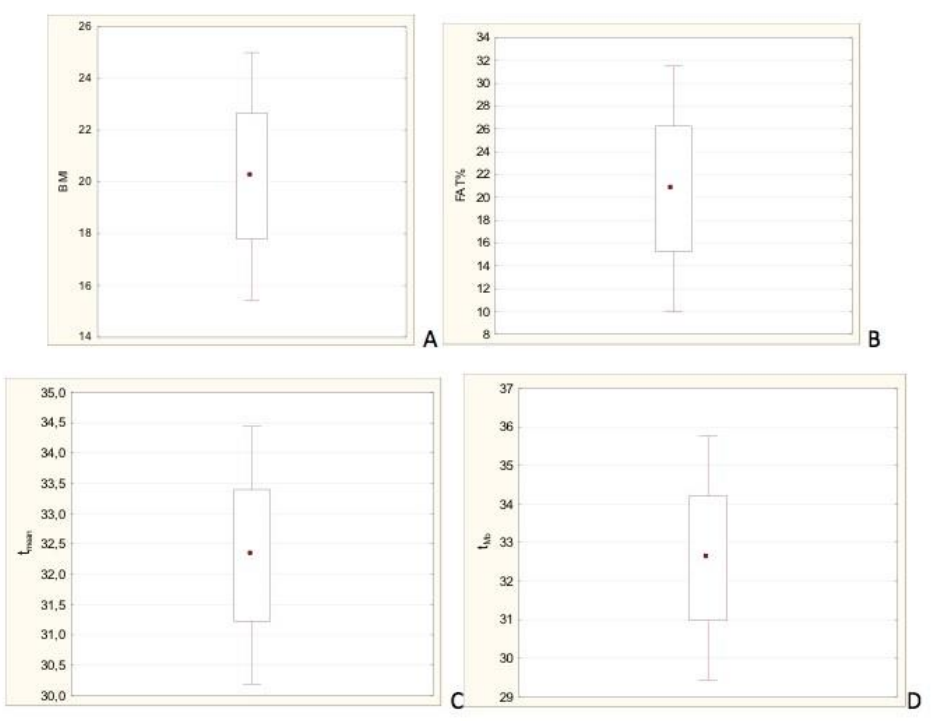

Figure. 3. BMI (A), FAT\% (B), tmean (A), and tMo (B) data distribution in the sample studied

In our opinion, the information on temperature differences between shins and hips ( $t$ hip $_{\text {mean }}-t$ $\operatorname{shin}_{\text {mean }}$ ) indirectly proves the study (27) revealing differences in the microcirculation of the different parts of the legs. For instance, the skin temperature of hips is higher than a shin temperature by $0.56 \pm 1.19 \mathrm{C}^{\circ}$; the maximal individual difference is $5.35 \mathrm{C}^{\circ}$. In some cases, the skin temperature of shins was higher than the temperature of hips by $3.62 \mathrm{C}^{\circ}$. Probably, these values are the result of the beginning of ischemic foot disturbances (28) detected by differences in the strategy of postural balance, walking, and/or flat feet (if any). The study (29) contains the data on the correlation between the balance and decrease in the function of mechanoreceptors and proprioceptors, dehydration, and hyperthermia. The study of Montgomery et al. revealed that the cooling of the large parts of lower limbs gradually affects dynamic balance (30). CieślińskaŚwider et al. found a correlation between abdominal obesity in women and postural instability (31). Studying the athletes' balance, we established that high values of a statokinesiogram area in vertical posture (more than $140 \mathrm{~mm}$ ) show discoordination in the functioning of shin and foot muscles (antagonist-synergist), which compensatory stimulates significant muscles efforts in order to align the axis of the foot, shin, knee, and hip. During the study with the participation of elite football players with Gastrocnemius-soleus equinus (GSE), 
Rodríguez-Sanz et al. revealed that the increase in skin temperature in the area of the anterior tibialis muscle is a direct result of muscle activity (32). Consequently, the study of leg temperature can provide the information on peculiarities of the postural balance strategy.

We performed non-parametric correlation analysis with the data obtained using impedancemetry and skin thermography, the main results of which are presented in Table 4 . The values obtained were lower than in the study of Neves E.B. et al. (24), which is possibly due to the specificity of the sample studied. We would like to pay attention to the insignificant values and number of correlations between skin temperature, FFM, and TBW, which require additional studies and making changes in the design of further works.

Nevertheless, all correlation values were at the level of statistical significance and allowed us to perform polynomial 2D scatterplots (Multiple and Regular) by choosing values of $r \geq 0.35$ between the data of the thermography and FAT\%.

Figure 3 demonstrates the distribution of BMI, FAT $\%, t_{\text {mean }}$, and $t_{\text {Mo }}$ data in the sample studied. Figure 3 demonstrates that a decrease in $t_{\text {mean }}$ is connected with an increase in FAT\%, and the range of $t_{\text {mean }}$ temperatures from 32.3 to $33.0 \mathrm{C}^{\circ}$ can be considered as optimal in accordance with normal FAT\% values for this sample. While studying the correlation between BMI and average skin temperature, we decided to divide $t_{\text {mean }}$ by the average temperature of the upper part of the body (trunk, neck, arms - $\mathrm{t}_{\text {mean }} \mathrm{T}$ ) and the average temperature of the lower part of the body (legs - $\left.t_{\text {mean }} D\right)$. As a result of significant differences (almost parallel, BMI increases as well as FAT\% with the increase in skin temperature), $\mathrm{t}_{\text {mean }} \mathrm{T}$ and $\mathrm{t}_{\text {mean }} \mathrm{D}$ were not revealed (Fig. 4). At the same time, to forecast FAT\% using $t_{\text {mean }} \mathrm{D}$, it is necessary to take into account the difference of temperatures as in the lower part the temperature is approximately $2.5 \mathrm{C}^{\circ}$ lower. In general, normal values of BMI are characterized by the range of temperatures from $32.5 \mathrm{C}^{\circ}$ to 33.5 $\mathrm{C}^{\circ}$ for $\mathrm{t}_{\text {mean }} \mathrm{T}$ and from $31.1 \mathrm{C}^{\circ}$ to $29.5 \mathrm{C}^{\circ}$ for $t_{\text {mean }} \mathrm{D}$.

The correlation between temperatures and FAT\% in local skin areas can be considered as one of the possible means to forecast body composition and to search for the patterns of the effect of postural balance and walking on the content of adipose tissue in the limbs. The study of posterior shin surface temperature and FAT\% demonstrated a significant correlation (Fig. 5). For example, in girls with an obvious deficiency of FAT\%, we registered a high shin temperature, which is almost $3 \mathrm{C}^{\circ}$ higher than in girls with the FAT of more than $30 \%$, which is probably connected with the postural balance and ankle strategy, when the main load falls on shin muscles. Consequently, the increase in body mass can result in adaptive changes, which can be measured with a certain accuracy by changing the strategies and using skin thermography.

A value within the range of $30.5-31.0 \mathrm{C}^{\circ}$ when FAT\% is at the level of 22-29\% can be regarded as a median value of $t_{\text {shin }} B$ normal temperature. A similar correlation was revealed comparing FAT\% and skin temperature of the left arm (shoulder area) (Fig. 6): the higher the temperature, the lower the FAT\%. However, using a graphical construction, we can estimate only FAT\% from 15 to $25 \%$, which is not sufficiently informative.

Fig. 6-10 demonstrate the correlation between local skin temperature and FAT\%. It should be noticed that a graphical construction of the skin temperature and FAT\% of arms, as well as $\mathrm{FAT}_{\text {TRUNK }} \%$ and waist temperature (back view), show the increase in the adipose tissue percentage with a decrease in skin temperature. However, despite the statistically significant correlations, in young women with low and normal body mass, this correlation can be regarded as a tendency, which does not reveal all anatomical and physiological reasons.

The analysis of shin temperature and FAT\% of the legs revealed an almost linear dependency: the decrease in temperature by $1 \mathrm{C}^{\circ}$ results in the increase in $\mathrm{FAT} \%$ by $1-1.5 \%$. Consequently, shin temperature can be the indicator of both FAT\% and FAT\% in legs.

\section{CONCLUSION}

In young women with underfat values of adipose tissue (less than $21 \%$ ), we revealed that these values were exceeded by $10.95 \%$ in legs compared to the trunk, which is almost identical to the range of maximal and minimal temperatures (about $6 \mathrm{C}^{\circ}$ ). It is possible that such a tendency should be taken into account during the study of nervous diseases and the assessment of treatment efficiency for diseases like Anorexia Nervosa. 


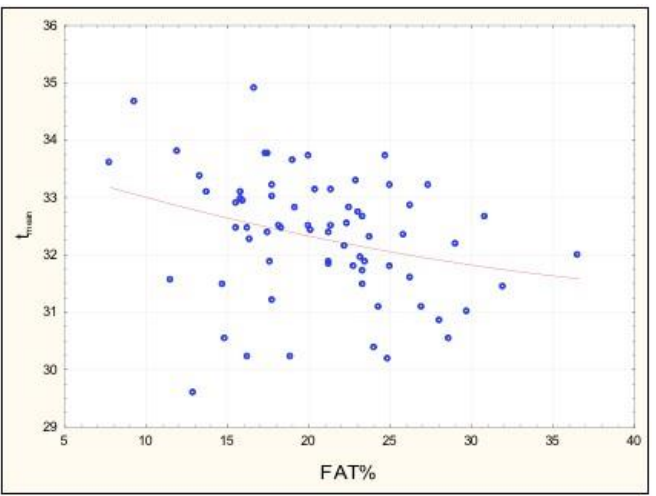

Figure. 4. Correlation between FAT \% and the average skin temperature of the body

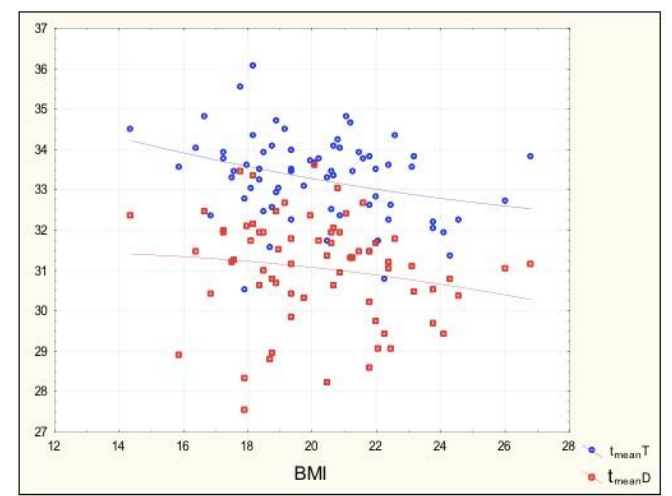

Figure. 5. Correlation between BMI and the average skin temperature of the upper and lower parts of the body

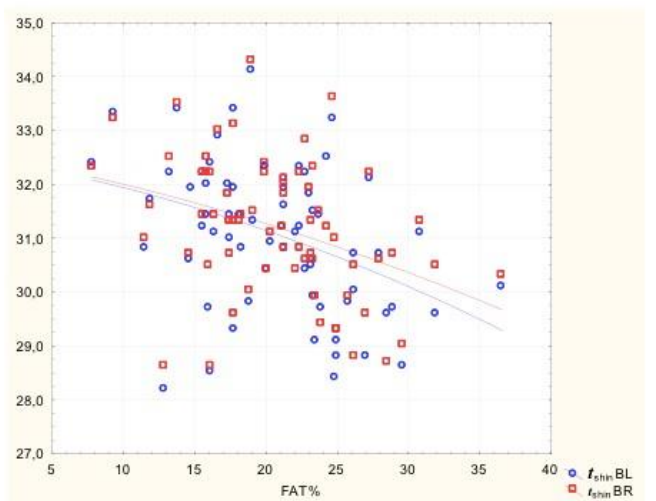

Figure. 6. Correlation between FAT\% and the average skin temperature of the right and left shins

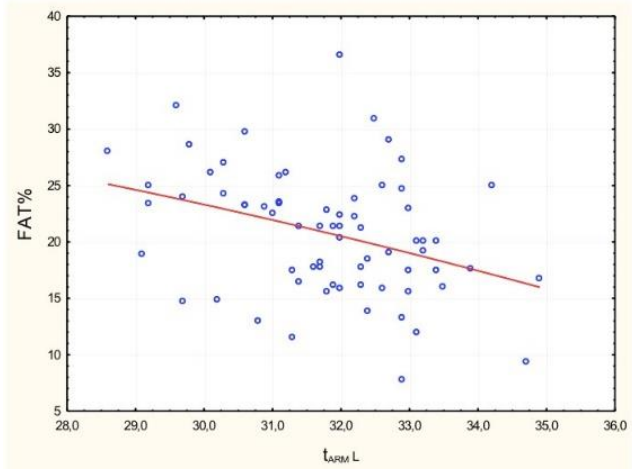

Figure. 7. Correlation between FAT\% and the average skin temperature of the left arm (shoulder area)

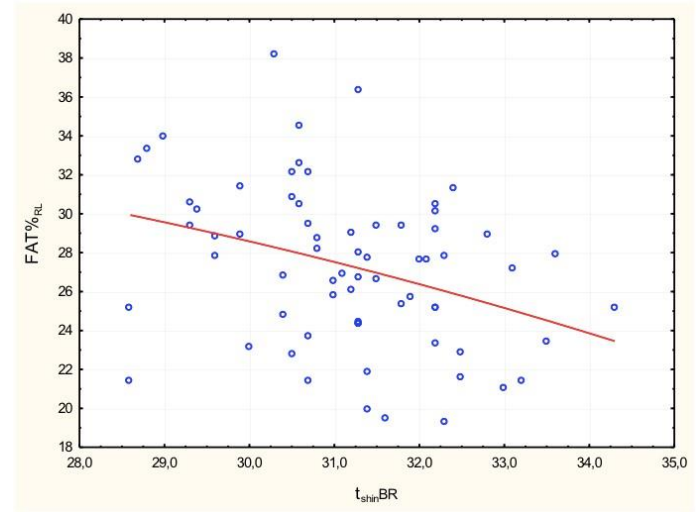

Figure. 8. Correlation between FAT\%RL and the average skin temperature of the right shin (back view)

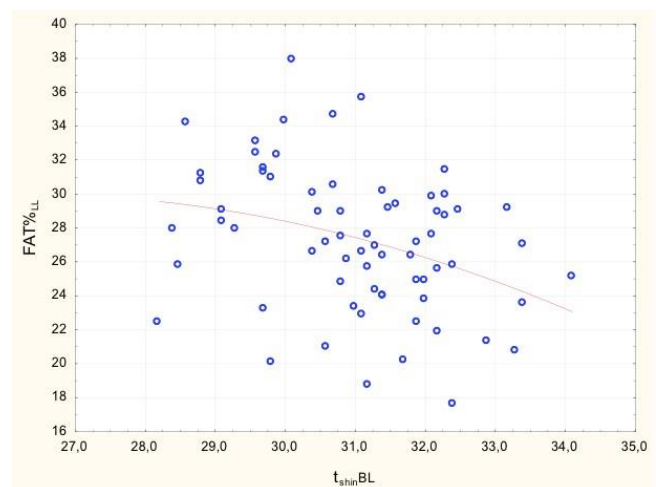

Figure. 9. Correlation between FAT\%LL and the average skin temperature of the left shin (back view)

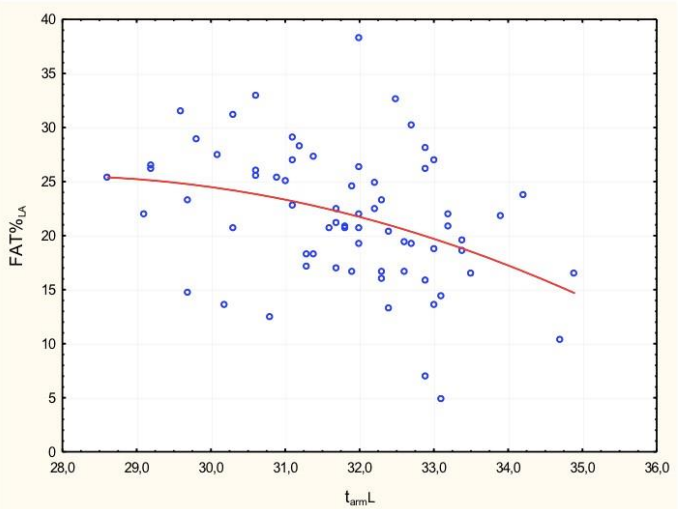

Figure. 10. Correlation between FAT\%LA and the average skin temperature of the left arm (back view)

The results of the correlation analysis of FAT\% data and skin thermography in young women demonstrate statistically significant correlations, which do not exceed -0.40 . Values of $\mathrm{t}_{\text {mean }}$ and FAT\% are connected $(\mathrm{r}=-0.36)$, but for this sample, shin temperature data $(r=-0.39)$ are more informative showing an almost linear correlation (decrease in temperature by $1 \mathrm{C}^{\circ}$ results in the increase in FAT\% by $1-1.5 \%$ ).

In young women with an obvious deficiency of FAT\%, we revealed a high temperature of shin skin, which is almost $3 \mathrm{C}^{\circ}$ higher than in women 
with FAT $\%$ of more than $30 \%$. Consequently, the information on temperature differences between shins and hips or shins and FAT\% could be the indicator for the strategy of postural balance. As a hypothesis for further studies, we can assume that women with higher values of shin temperature use the ankle strategy of postural balance, while women with higher values of hip temperature use the hip strategy.

\section{Limitations and Further Research}

The experiments were conducted on healthy volunteers in accordance with the approval granted by the Ethical Committee of the University, prior to the study, the participants' informed consent was obtained.

\section{APPLICABLE REMARKS}

- The authors suggest that the correlations established between FAT and skin temperature, combined with the results of further studies, will allow developing a brand-new algorithm and state-of-the-art equipment for monitoring human health with IR thermography.
- In particular, the peculiarities revealed in the range of hip and shin temperatures can be used as criteria for diagnosing, for example, flat feet or varicose veins.

- A wide range of temperatures can also be a sign of neurologic, CNS-related, endocrine, and metabolic disorders.

- Early diagnostics of skin temperature with IR thermography can be used as an additional diagnostic tool in orthopedics, nutrition science, and endocrinology.

\section{Conflict of Interests}

The authors claim that there is no known conflict of interests.

\section{Acknowledgments}

This work was supported by the Ministry of Education and Science of the Russian Federation [grant No 19.9733.2017/BP].

The work was supported by Act 211 Government of the Russian Federation, contract № 02.A03.21.0011.

\section{REFERENCES}

1. Frim J, Livingstone SD, Reed LD, Nolan RW, Limmer RE. Body composition and skin temperature variation. J Appl Physiol (1985). 1990;68(2):540-543. doi: 10.1152/jappl.1990.68.2.540 pmid: 2318765

2. Liang MT, Su HF, Lee NY. Skin temperature and skin blood flow affect bioelectric impedance study of female fat-free mass. Med Sci Sports Exerc. 2000;32(1):221-227. doi: 10.1097/00005768200001000-00033 pmid: 10647553

3. Prisby R, Glickman-Weiss EL, Nelson AG, Caine N. Thermal and metabolic responses of high and low fat women to cold water immersion. Aviat Space Environ Med. 1999;70(9):887-891. pmid: 10503754

4. Mozaffarieh M, Fontana Gasio P, Schotzau A, Orgul S, Flammer J, Krauchi K. Thermal discomfort with cold extremities in relation to age, gender, and body mass index in a random sample of a Swiss urban population. Popul Health Metr. 2010;8:17. doi: 10.1186/1478-7954-8-17 pmid: 20525354

5. Costa CMA, Moreira DG, Sillero-Quintana M, Brito CJ, de Azambuja Pussieldi G, de Andrade Fernandes A, et al. Daily rhythm of skin temperature of women evaluated by infrared thermal imaging. J Therm Biol. 2018;72:1-9. doi: 10.1016/j.jtherbio.2017.12.002 pmid: 29496001

6. Meeuwsen S, Horgan GW, Elia M. The relationship between BMI and percent body fat, measured by bioelectrical impedance, in a large adult sample is curvilinear and influenced by age and sex. Clin Nutr. 2010;29(5):560-566. doi: 10.1016/j.clnu.2009.12.011 pmid: 20359792

7. Frankenfield DC, Rowe WA, Cooney RN, Smith JS, Becker D. Limits of body mass index to detect obesity and predict body composition. Nutrition. 2001;17(1):26-30. doi: 10.1016/s08999007(00)00471-8 pmid: 11165884

8. Hung SP, Chen CY, Guo FR, Chang CI, Jan CF. Combine body mass index and body fat percentage measures to improve the accuracy of obesity screening in young adults. Obes Res Clin Pract. 2017;11(1):11-18. doi: 10.1016/j.orcp.2016.02.005 pmid: 26944683

9. Choi JK, Miki K, Sagawa S, Shiraki K. Evaluation of mean skin temperature formulas by infrared thermography. Int J Biometeorol. 1997;41(2):68-75. pmid: 9429341 
10.Fernández-Cuevas I, Bouzas Marins JC, Arnáiz Lastras J, Gómez Carmona PM, Piñonosa Cano S, García-Concepción MÁ, et al. Classification of factors influencing the use of infrared thermography in humans: A review. Infrared Phys Technol. 2015;71:28-55. doi: 10.1016/j.infrared.2015.02.007

11.Lahiri BB, Bagavathiappan S, Jayakumar T, Philip J. Medical applications of infrared thermography: A review. Infrared Phys Technol. 2012;55(4):221-235. doi: 10.1016/j.infrared.2012.03.007

12.Ludwig N, Formenti D, Gargano M, Alberti G. Skin temperature evaluation by infrared thermography: Comparison of image analysis methods. Infrared Phys Technol. 2014;62:1-6. doi: 10.1016/j.infrared.2013.09.011

13. Kotler DP, Burastero S, Wang J, Pierson RN, Jr. Prediction of body cell mass, fat-free mass, and total body water with bioelectrical impedance analysis: effects of race, sex, and disease. Am J Clin Nutr. 1996;64(3 Suppl):489S-497S. doi: 10.1093/ajcn/64.3.489S pmid: 8780369

14. Shafer KJ, Siders WA, Johnson LK, Lukaski HC. Validity of segmental multiple-frequency bioelectrical impedance analysis to estimate body composition of adults across a range of body mass indexes. Nutrition. 2009;25(1):25-32. doi: 10.1016/j.nut.2008.07.004 pmid: 18723322

15.Ellis KJ, Bell SJ, Chertow GM, Chumlea WC, Knox TA, Kotler DP, et al. Bioelectrical impedance methods in clinical research: a follow-up to the NIH Technology Assessment Conference. Nutrition. 1999;15(11-12):874-880. doi: 10.1016/s0899-9007(99)00147-1 pmid: 10575664

16. Sun G, French CR, Martin GR, Younghusband B, Green RC, Xie YG, et al. Comparison of multifrequency bioelectrical impedance analysis with dual-energy $\mathrm{X}$-ray absorptiometry for assessment of percentage body fat in a large, healthy population. Am J Clin Nutr. 2005;81(1):74-78. doi: 10.1093/ajcn/81.1.74 pmid: 15640463

17.Barnes RB. Thermography of the human body. Science. 1963;140(3569):870-877. doi: 10.1126/science.140.3569.870 pmid: 13969373

18. Hayward MG, Keatinge WR. Roles of subcutaneous fat and thermoregulatory reflexes in determining ability to stabilize body temperature in water. $J$ Physiol. 1981;320:229-251. doi: 10.1113/jphysiol.1981.sp013946 pmid: 7320937

19. Marins JC, Fernandes AA, Cano SP, Moreira DG, da Silva FS, Costa CM, et al. Thermal body patterns for healthy Brazilian adults (male and female). J Therm Biol. 2014;42:1-8. doi: 10.1016/j.jtherbio.2014.02.020 pmid: 24802142

20.Leblanc J. Subcutaneous fat and skin temperature. Can J Biochem Physiol. 1954;32(4):354-358. pmid: 13160839

21. Savastano DM, Gorbach AM, Eden HS, Brady SM, Reynolds JC, Yanovski JA. Adiposity and human regional body temperature. Am J Clin Nutr. 2009;90(5):1124-1131. doi: 10.3945/ajen.2009.27567 pmid: 19740972

22. Chudecka M, Lubkowska A, Kempinska-Podhorodecka A. Body surface temperature distribution in relation to body composition in obese women. $J$ Therm Biol. 2014;43:1-6. doi: 10.1016/j.jtherbio.2014.03.001 pmid: 24956951

23. Chudecka M, Lubkowska A. Thermal maps of young women and men. Infrared Phys Technol. 2015;69:81-87. doi: 10.1016/j.infrared.2015.01.012

24.Neves EB, Salamunes ACC, de Oliveira RM, Stadnik AMW. Effect of body fat and gender on body temperature distribution. J Therm Biol. 2017;70(Pt B):1-8. doi: 10.1016/j.jtherbio.2017.10.017 pmid: 29108552

25.Fryar CD, Gu Q, Ogden CL. Anthropometric reference data for children and adults; United States, 2007-2010. Vital Health Stat. 2012;11:252-257.

26. Gallagher D, Heymsfield SB, Heo M, Jebb SA, Murgatroyd PR, Sakamoto Y. Healthy percentage body fat ranges: an approach for developing guidelines based on body mass index. Am J Clin Nutr. 2000;72(3):694-701. doi: 10.1093/ajcn/72.3.694 pmid: 10966886

27. Balaz D, Komornikova A, Kruzliak P, Sabaka P, Gaspar L, Zulli A, et al. Regional differences of vasodilatation and vasomotion response to local heating in human cutaneous microcirculation. Vasa. 2015;44(6):458-465. doi: 10.1024/0301-1526/a000469 pmid: 26515223

28. Staffa E, Bernard V, Kubicek L, Vlachovsky R, Vlk D, Mornstein V, et al. Infrared thermography as option for evaluating the treatment effect of percutaneous transluminal angioplasty by patients with 
peripheral arterial disease. Vascular. 2017;25(1):42-49. doi: 10.1177/1708538116640444 pmid: 26993145

29.Zemkova E, Hamar D. Physiological mechanisms of post-exercise balance impairment. Sports Med. 2014;44(4):437-448. doi: 10.1007/s40279-013-0129-7 pmid: 24264058

30. Montgomery RE, Hartley GL, Tyler CJ, Cheung SS. Effect of segmental, localized lower limb cooling on dynamic balance. Med Sci Sports Exerc. 2015;47(1):66-73. doi: 10.1249/MSS.0000000000000379 pmid: 24870570

31.Cieslinska-Swider J, Furmanek MP, Blaszczyk JW. The influence of adipose tissue location on postural control. J Biomech. 2017;60:162-169. doi: 10.1016/j.jbiomech.2017.06.027 pmid: 28705486

32. Rodriguez-Sanz D, Losa-Iglesias ME, Lopez-Lopez D, Calvo-Lobo C, Palomo-Lopez P, Becerro-deBengoa-Vallejo R. Infrared thermography applied to lower limb muscles in elite soccer players with functional ankle equinus and non-equinus condition. PeerJ. 2017;5:e3388. doi: 10.7717/peerj.3388 pmid: 28560116 